\title{
Role of Local Government and Non-profit Organizations Toward Social Services For Families. Theoretical and Practical Approaches (North Albania Case)
}

\author{
Brilanda Lumanaj, $\mathrm{PhD}$. \\ Department of Psychology and Social Work, \\ Faculty of Education Sciences, \\ University of Shkodra "Luigj Gurakuqi", \\ Shkodra, Albania, \\ landa_z@yahoo.com
}

\begin{abstract}
Family is an important human capital. Family support with social services is an obligation for local government structures and non-profit organizations. The process of decentralization increases the responsibility of local government structures to support families with social services. This study aims to analyze the theoretical approaches regarding the role of local government and non-profit organizations with a focus on social services family. The study is focused on the analysis of national and international documents related to the field study. The paper also has the objective to present an overview of the role of local government and NGOs in the regions of Northern Albania regarding the provision of social services for family. The field study was done in the northern region of Albania, including her four Districts, in its main cities: Shkodër, Lezhë, Kukës and Peshkopi. In the study participated 44 subjects in total, 23 of them are representative of local, regional and central institutions and 21 representatives of NGOs that operate in the filed study. A qualitative research method has been used. The findings of this study reflect the fact that, families in Northern Albania profit a small amount of services from public sector and a variety of services from non-profit organizations. The conclusions of this paper represent the theoretical elements in national and international context toward the role of local government and NGOs focused in social services for families.
\end{abstract}

Keywords: Local Government, Public Sector, Non-profit Organizations, Social Services for Families, North Albania

\section{Introduction}

Feely \& Gottlieb et al., (2000) and McCubbin (1993) explain that the support of family from the society and community can provide a higher sense of belonging and cohesion (cited by Black, K. \& Lobo, M., 2008). Wax (2003) in his studies determines not only the government but also all members of society are responsible for the protection of human rights. He argues the fact that one should not take all the credit for what it does and achieves, as everything happens in a context that is closely related to society and its institutions. European Committee for Social Cohesion (2004) in his publication "A New Strategy for Social Cohesion", among other emphasizes that society and the social network has a responsibility to protect the family. Because traditional care institutions play a small role in this regard, it is important to develop alternative means of care wherever possible.

Civil society, including NGOs, is an important component that contributes in any democratic society. The main objective of civil society (and therefore also of NGOs) is to provide services and representation of the interests of the most vulnerable groups of society. NGOs should try to empower and mobilize these vulnerable sectors, so that they are able to protect their rights and enhance the quality of life and standard of living (The Youth Development Network, 2008).

Based on these arguments it is important to analyze the theoretical and practical approaches regarding the role of local government and NGOs in providing social services focusing on family.

\section{Methodology}

This study aims to analyze the theoretical approaches regarding the role of local government and non-profit organizations with a focus on social services family. The study is focused on the analysis of national and international documents related to the field study. The paper also has the objective to present an overview of the role of local government and NGOs in the regions of Northern Albania regarding the provision of social services for family. A qualitative research 
method has been used to achieve this objective. The instrument used for data gathering is the semi-structured interview. The field study was done in the northern region of Albania, including her four Districts, in its main cities: Shkodër, Lezhë, Kukës and Peshkopi. In the study participated 44 subjects in total, 23 of them are representative of local, regional and central institutions and 21 representatives of NGOs that operate in the filed study.

In order to achieve the goals, the study is focused on three research question, which are:

Which is the role of local government and non-profit organizations toward social services for families through theoretical approaches?

Which is the role and contribution of local government toward social services for families offered by public sector in the northern regions of Albania through the perceptions of representatives of local, regional and central governance institutions?

Which is the role and contribution of non-profit organizations toward social services for families offered by the participating NGOs in the northern regions of Albania through the perceptions of representatives of NGOs?

\section{Sampling/Participants}

In the study participated the representatives of non-profit organizations and the representatives of local, regional and central governance institutions which operate in the northern regions of Albania. The NGOs offer social services related with families. Specifically, participated in this study the NGOs and the state institutions that operate in these districts: Shkodër, Lezhë, Kukës and Peshkopi. A total of 44 semi structured interviews were completed. Information about the selection of the organizations was provided by the local public social services entities which have all the contacts of the non-profit organizations that operate in the field of family services and also was realized the consultation with "The Map of Social Services in Albania".

\section{General data for the respondents}

In this study participated 21 representatives of non-profit organizations that operate with social services for families and 23 representatives of local, regional and central governance institutions that operate in the field study. From 44 participants, 32 participants were female and 12 of them are men. The participants are of different ages. 9 participants are aged 26-35 years, 11 participants are aged until 25 years, 15 participants are aged $36-45$ years, 4 participants are aged $46-55$ years and 5 of them are aged 56-65 years. Regarding the level of education, 28 respondents have higher education $(62.8 \%), 12$ respondents have master degree level $(27.9 \%)$ and 4 of them have secondary education (9.3\%). Participants, who filled the semi-structured interview, belong to different professions. Only 38 of them accepted to declare their profession. 12 of the respondents are social workers, 4 of them are psychologists, 6 of the respondents are lawyers, 7 of them are teachers, 5 of them are economists, 1 of the respondents is an environment expert, 1 respondent is sociologist, 1 of them is agronomist and also 1 respondent is representatives of political science. The representatives of non-profit organizations, who filled semi-structured interviews, have different years of work experience in respective organizations/institutions. 19 respondents have 1-5 years work experience and also 19 of them have 6-10 years work, 5 participants have more than 10 years work and 1 respondent has one year work experience. Representatives of non-profit organizations and local, regional and central institutions have an average of 6.3 years work experience in respective organization/institution. Regarding the representatives of local, regional and central governance institutions, 16 participants are representatives of public sector of social services (representatives of four Municipalities, the respective Directories of Social Services) and 7 participants are representatives of regional and central institutions.

\section{Instrument}

The interview's questions have been organized in order to achieve the study objectives and to address research questions. Data collection was achieved through the instrument of the semi-structured interviews. The semi-structured interviews include thirteen questions, where six of them provide socio demographic data. Some of the topics included in the interview were part of the dissertation theme, which is related to the evaluation of social services for family offered by public sectors and non-profit organizations in northern regions of Albania. In this article are treated only topics related to perception of non-profit organizations representatives, and local, regional and central institutions representatives concerning the role and contribution of respective institucions and organizations toward the social services for families. 


\section{Procedure}

The data were gathered via email. The semi-structured interview provided for the participants information about the aim and the main objectives of the study. The participants were presented with the confidentiality policy and anonymity was insured not using their real names and presenting the data in an aggregate form (there are used codes). The instrument have been filled out by the NGOs and local, regional and central institutions representative and they were sent via email (the participants felt more comfortable in this way and manage the time of completion of the instrument according to their agenda), in order to respect their agenda and necessary time to complete them.

\section{Method of analysis}

Each interview is dumped into a database in Microsoft Excel program, and then are defined the codes for every participant. Determination of the main themes and creation of categories was conducted manually. Creating categories was conducted in two phases. Terminology used by subjects may be helpful for analysis and data transcripts (I. Meho, L., 2006). Specifically the process of transcription was a strong point of data analysis in this study, given that semi-structured interviews emailed and the respondents had enough time for completion of the interview. Another helpful element in this process was the considerable professional experience of subjects in social services field.

\section{Findings of the study}

\section{Theoritical approaches}

\section{The role of local government toward social services for families}

Government plays a key role in the design of effective policies for the family. Thus Lefebvre, P. Merrigan, P., (2003) define as the roles and principles of government regarding public support of families, such as:

- The society should mainly support families because children generate positivity "external" or social benefits.

- Reducing the "tax burden" families with dependent children, compared to persons living alone or households without dependent children or with the support of non-taxable income based on the number of children in the family, regarded as the most simple to help families with children to achieve adequate standard of living. This traditional approach of transfer tax respects the principle of horizontal equity.

- The tax system must also distribute fairly the amount people pay taxes according to ability to pay differential.

- These tax policies should be designed in order to maintain incentives, particularly in the context of family support.

- Can be efficient and fair to give material support to the family, this positively affects child development, recognizing that the welfare of the child depends on the allocation of resources within the family.

Munday, B. (2007) presents a guide which covers a number of aspects of the involvement of users in collaboration with local agencies, as well as governmental organizations. This guide contains some basic principles such as:

- Information for users - current and potential users of social services should be provided with clear information and correct all aspects of services available. Lack of clarity can lead to frustration and consequently unwillingness to engage.

- The right to specific ways of involvement - in many places a user has the right to be informed through contacts his / her data with an agency. This should be extended to all countries, recognizing that users need encouragement and practical support to exercise this right. Family members and caregivers of users should have the right to involvement in well-defined circumstances, for example: when an elderly person is in residential long-term care; a child is in public care, etc. The need for these rights is often not recognized and enforced.

- Involving users in planning and delivery service - this is a good practice and based on the statements of the users, where they should be involved in the early stages of the planning process services. Direct representation of recommended users about specific services, especially for user services at risk. Organizations that provide social services should have as their policy the practice of user involvement as members of decision making bodies at all levels within the organization. Users should also be included in assessing the results of agency services, including those in the selection of criteria for evaluation. 
In Albanian context, has been increased the role of local government in providing social services. A special importance is playing the reform of the system of social services where through the decentralization process has been strengthened the local government positions. Thus, decentralization of residential care services depending on local units and gradually shift toward community-based services, is accomplished by increasing the capacity of local government to increase programming the social services, as well as geographical expansion and diversification of services in accordance with needs of the population.

Through the Social Services Strategy (2005-2010) and Law No. 9355 on "Assistance and Social Services" (2005) opened the way to the local government for the deinstitutionalization and decentralization of care institutions, where the services will be closer to family and community. This reform also encourages civil society in ensuring and developing new services to social care in partnership with local government. Establishing and monitoring of service standards make possible the improvement of the quality of services.

Decentralization Strategy and Local Government noted that the vision for local government is in accordance with the provisions of the Constitution of the Republic of Albania, with the European Charter of Local Autonomy. The Constitution defines the basic structure of local government in Albania. Here's foreseen the responsibility of local government - counties and municipalities/cities, for delivering and distributing goods and services.

Law no. 8652, dated 31.07.2000 "On the organization and functioning of local government" also contributes to the regulation, organization and functioning of local government units in the Republic of Albania (Article 1).

While the European Charter of Local Autonomy in its preamble states that the protection and strengthening of local autonomy in various European countries constitutes an important contribution to building a Europe based on the principles of democracy and the decentralization of power.

\section{The role of nonprofit organizations in providing social services}

Supporting families and individuals with social services is a process that requires the cooperation of all stakeholders. Non-profit organizations play an important role in providing social services, a role which for some time was neglected by governments (Bastagli, F., 2013). One of the defining elements of good practices of social services is the cooperation between local government and civil society. Best practices of social services are those that are effective and responsive to the customer in particular, and the general public. Thus, a fundamental element of these best practices is the formal and informal networks between service providers and other partners (Fultz, E., M. Tracy, 2004).

Heintz, S., (2006) in his study notes that, increasingly, the existence of NGOs has proven to be a necessity and not a luxury for companies throughout the modern world. He notes that NGOs play a key role in the development of society by enabling people to work together to promote voluntary social values and civic purposes. Heintz lists, also three main roles of NGOs in modern society. First, NGOs provide the opportunity for self-organization of society, encouraging citizens to promote social values through volunteer activities, as well as promoting local initiatives to solve problems in various fields. Secondly, NGOs maintain a unique and essential space between profit and government sector, they can serve as watchdogs of government and business. Third, experiments enable NGOs and social change challenges facing the public and private sector can not or do not realize, offering numerous models of service delivery that are considered "best practice" design, tested and improved over many years of experimentation by NGOs (quoted from the report of The Youth Development Network, 2008).

Halloran, J. and Calderon, K., (2004-2005), argue that the cooperation and involvement of local stakeholders in the design of programs, assists in securing and enhancing quality service delivery. European Social Platform (2008) noted noted that for guaranteeing the quality of social services is very important the principle of cooperation with the community and other stakeholders. Nonprofit organizations contribute to the realization of social protection to vulnerable families by supporting them with social services of different dimensions. European Social Charter (1961), Article 14 (paragraph 2), regarding the right to benefit from social welfare services, noted that the signatories shall encourage the participation of individuals and voluntary organizations in the creation and maintenance of such services.

The role and contribution of local government toward social services for families offered by the public sector in the northern regions of Albania through the perceptions of representatives of local, regional and central governance institutions 
Representatives of local government institutions (municipal units), regional and national generally explain that public sector of social services have improved in terms of providing social services to the family. The contribution of this sector is closely related to the elements of organizing services in general, with the opening of offices for social services, addressing the phenomenon of domestic violence, providing financial support to families, the functioning of the protection of rights children, supporting families with a parent, as well as setting up temporary foster care service for children.

"Has contributed to the family services, offering support for the protection of children rights, financial support to facilitate the economic problems that families have, as well as services provided to individuals within the family, vocational opportunities, etc..." (Social Worker)

"The provision of community services at the community day care centers for families in need, the center of which are dependent on the City." (Social Worker)

"Has contributed by creating a new vision and perspective of the welfare system and the coordination and management of resources in the area, answering the demands and needs of each category." (Psychologist)

In many cases, social services of the public sector, in terms of social services with a focus on family, are treated by respondents as services that are performed in cooperation with public institutions and NGOs. Concretely, the stakeholders of the network of cooperation with institutions are: social administrators, school psychologists, family doctors and other representatives of public institutions. While cooperation with NGOs has helped the sector to identify and refer cases, organizing joint training, and organizing technical seminars on various issues related to family.

"Child Protection Unit also collaborates with social service administrators, school psychologists, family doctor, the responsible authorities, social workers, public and private service centers, in order to improve the situation of child protection in the territory of municipality. "(Social Worker)

"Our institution, in collaboration with various NGOs, has supported social reforms undertaken by these organizations for families in need as capacity building of local government for social services in the community through the organization of training sessions." (Social Worker)

One of the elements estimated by respondents, as a contribution to the improvement of social services for family, is the establishment of the needs assessment committee, as well as the contribution of public social services offices to sensitize the community and families of the necessity of social services.

"It has been established the Committee of Needs Assessment, which reviews applications of the citizens who need care services and collating sets of clients in residential centers, wich are subject to the Municipality as the orphanage, development center and the home of the elderly."(Social Worker)

Respondents generally evaluate family psychological support, vocational training, support materials, supporting families and strengthening small business financial, improving parent-child report, empowering parents in the education of children, and child protection and women from violence, as services that strengthen families and improve their life. However, emphasized by a large part of respondents that these services need further improvements. Considerations appear not very positive about family social services provided by the municipalities of the study area. Specifically, it is emphasized which these services do not fulfill different needs of vulnerable families, mainly related more to the individual and not the family system. It is also emphasized that there are few family services and it is necessary to extend them in all local units.

"I appreciate as ongoing services; these services need to be strengthened, to be more realistic and closer to family. Actually in my opinion they are not in the level of required standards, as long as they do not constitute a specific item in the budget of the Municipality, as long as there are numerous needs of all natures which have families. "(Social Worker) Worker)

"Local governments should open as many community centers for people in need and their families."(Social

"Northern Areas have a positive attempt at providing these services, but still too little to empower family. Currently programs offer more services to the individual and not look closely connected with the family. "(Sociologist)

Representatives of central state institutions, evaluate at a medium level the process of standards implementation of social services at the local level, referred to municipalities of the study area. They explain that in these municipalities are making efforts to meet these standards, but their implementation is mostly related to the physical aspects and not those psycho-social and family needs. Are noticed problems and deficiencies in the professional capacity of staff delivering social services, lack of infrastructure, and lack of evidence drafting and adoption of standards, as key indicators of their performance. 


\section{The role and contribution of non-profit organizations toward social services for families offered by the participating NGOs in the northern regions of Albania through the perceptions of representatives of NGOs.}

NGOs representatives explain that the organizations involved in the study, have contributed to the field of social services for family. This contribution is related to the variety of services offered to different target groups in need. They explain that they have contributed to the establishment of more favourable policies for families and children through child protection approach. Opening of various social centers for youth, children and persons with disabilities, protection of women from domestic violence, the center for the elderly, homes for teenage girl coming from state residential institutions, etc., have contributed to improving the life of the members of their families.

"In the organization where I work are very valuable recommendations for strengthening the family and the inclusion of vulnerable groups in social policy." (Lawyer)

"From the organization of focus groups with children, families, schools, with representatives of Municipality or Commune level, problems were identified from the perspective of children and their families. These reports are offered and have been available to local governments, and for any other institution responsible for the realization of children's rights and civil society organizations, with the aim of formulating favorable policies for families and children. "(Lawyer)

"The creation of self-help groups for parents and families of the families who have children with disabilities. Setting up offices for the protection of children and providing services to children and families. "(Executive Director)

These social services have contributed to improving the life of families, increasing socio-economic status of families in need, protecting and monitoring the rights of children, providing psychological support for parents in the education of children and overcome the social problems which they have. Respondents explain, also, that they have supported families in economic difficulties with materials, have provided health care for these families and have deliver services to minimize the risk of removing the children from the family of origin, providing legal support. One of the supports which were realized by a large part of NGOs is the protection of women and children from domestic violence. Part of the activities of a small number of NGOs has been the socialization of children and youth through educational programs and summer schools. These services have contributed in particular to improving the social life of families, improving interpersonal relationships, strengthening the role of women in the family and community, improving the methods of parenting and strengthening of some families to open their business private.

"We have contributed offering support and treat members of the family; we help the improvement of the life of whole family." (Psychologist)

"Through the projects development, which aimed the involvement of women who are part of vulnerable families in social and economic life, intending to be an important part of organizing family life." (Teacher)

"Improving the economic position of women in need with the aim of reducing violence against them and increasing their role in the family and community." (Executive Director)

Respondents explain that, in addition to providing concrete services, organizations have contributed to the organization of meetings about raising awareness of families, women and the community for their rights, information campaigns about domestic violence, awareness meetings related to early childhood education and the role of parents in education, informational meetings regarding family planning, school meetings with parents of children problems, etc..

"Through information campaigns on the causes and consequences of domestic violence have affected the mentality of men to treat women, normally the role of women in the family has increased, this improved standard for family life. Women themselves are empowered through access to information and knowledge of their rights. "(Panellists)

"By supporting women to develop their capacities, encouraging them to take initiatives to strengthen their position in the family." (Psychologist)

To implement these services is cooperating with local government, community and NGOs. The respondents claim that they have made a lot of meetings in order to recommend the improvement of social services in general, and social services for families in particular. They evaluate the annual reports of the organizations associated with the presentation of the situation of families in need, as a contribution to the local government.

(Social Worker)

"The organization has contributed to the provision of services in patnership with local government actors." 
"The organization has contributed to social services with a focus on family. The purpose of the organization is in collaboration with other stakeholders to positively affect the family. "(Manager)

\section{Conclusions}

From review of the literature results that family support with social services is a responsibility of local government and nonprofit organizations. The family should be considered as an important part of social policy. In this way, the existence of such services provided by the welfare state in the future determines the stability of the family. Needs to be emphasized that the provision of quality social services is very important to support families in need. Representatives of municipal units of the study area see the improvement of social services for the family of these units associated with addressing the phenomenon of domestic violence in some municipalities, the functioning of the protection of children's rights, providing financial support for families in need, supporting families with a parent, as well as the establishment of temporary foster care service for children. This improvement was associated with psychological support for families in need, the professional training of members, with material support for families in need, supporting families and strengthening small business financial, improving the parent-child relationship, empowering of parents in children's education and, protecting children and women from violence. However, it should be emphasized that a significant proportion of respondents, including representatives from state institutions, believe that the social services for families offered by public sector, do not fulfill the diverse needs of families and are more related to the individual and not the family system.

The study showed that the contribution of NGOs in the field of social services for families in the study area is larger. They offer different services. Through the establishment of new centers, provision of different services and community meetings, NGOs have contributed for the improvement of the life of families in need. Generally they have contributed to the growth of socio-economic status and professional families in need, protecting the rights of children, offering psychological support to family members for diverse problems in health care and providing support legal. The study conducted in the regions of northern Albania showed that families in the study area profit a small amount of services from public sector and a variety of services from nonprofit organizations. The contribution of organizations in the social services for family field is larger. The study came to reflect that public social services are limited and individual based.

\section{Recommendations}

Based on the empirical findings and on conclusions derived, it is necessary to consider certain recommendations related increasing of the role and contribution of public sector and NGOs toward social services for families.

\section{Recommendations for public sector services in municipal units}

- Awareness of the municipal units for their responsibility regarding the provision of social services for families.

- Strengthening the capacity of professional staff of municipal units in terms of qualifications for the organization and delivery of social services for family.

- Provision of services for victims of domestic violence in all municipal units of the northern part of the country.

- Opening of community-based centers in all municipal units.

- $\quad$ Establishing new social services for families in need and the extending their planning in other municipalities and communes. These services must be focused on treating the family as a system, through needs assessment and psychosocial health of all family members. During this process it is important to include community members and families, as are defined by the standards of social services in our country.

- Building financial capacity at the local level to support families in need.

- Increase collaboration with local institutions and NGOs through more frequent meetings with all stakeholders regarding the improvement of the legal framework, the joint offering suggestions for improvement of social services for family.

- Treatment the priority of families who have the most urgent need for support and social services.

- Improvement of financial support to families in need, alternated with other services and psycho-social services in the community. 


\section{Recommendations for NGOs}

- Despite the fact that NGOs provide diversity services for family is necessary to provide services focusing more on psychological support to family members in order to improve the relations between them. It is necessary, also, that services are organized from the perspective of family strengths which evaluates as important the capacity and needs of each family member.

- NGOs, in some cases, need to improve their working standards, in order to be in cooperation with the community and families.

- $\quad$ NGOs should expand the territorial scope of their services to support families in need.

- Organizations should mobilize for the support in terms of funding from local government regarding family social services.

- $\quad$ NGOs should encourage local governments to implement the legal framework in relation to social services. In this process they should include recipients of services and families in need.

\section{References}

[1] Bastagli, F., (February 2013). Feasibility of social protection schemes in developing countries. European Union (12 February 2013). p. 12.

[2] Black, K. \& Lobo, M., (2008). A Conceptual Review of Family Resilience Factors. Journal of Family Nursing. Volume 14 Number 1. February 2008, 33-55.

[3] European Foundation for the Improvement of Living and Working Conditions. [Online] Available:

[4] www.eurofound.europa.eu/pubdocs/.../ef0101en.pd. p. 2.

[5] European Social Charter, (Article 14). [Online] Available:

[6] http://www.coe.int/t/dghl/monitoring/socialcharter/presentation/escrbooklet/English.pdf

[7] European Charter of Local Autonomy. [Online] Available: https://wcd.coe.int/ViewDoc.jsp?id=1962223\&Site=COE

[8] Fultz, E., M. Tracy., (2004). Good Practices in Social Services Delivery in South Eastern Europe. Budapest, International Labor Office. p. 17

[9] Halloran, J. and Calderon, K.., (2004-2005). Access to Quality Social Services. A Strategy Paper. European Social Network. Published by European Social Network (ESN) in 2005. p. 4-5.

[10] I.Meho, L., (2006). E-Mail Interviewing in Qualitative Research: A Methodological Discussion. Journal of the American Society for Information Science and Technology, 57(10):1284-1295, 2006. [Online] Available: http://eprints.rclis.org/8377/1/email-interviewing.pdf

[11] Lefebvre, P., Merrigan, P., (2003). Assessing Family Policy in Canada. A New Deal for Families and Children. Vol. 9, no. 5 June 2003 ISSN 0711-0677. [Online] Available: www.irpp.org/choices/archive/vol9no5.pdf. p.17.

[12] Ligji Nr. 9355, datë 10.03.2005,"Për Ndihmën dhe Shërbimet Shoqërore". [Online] Available: http://www.mpcs.gov.al/ligje-legiislacioni-social-ligje

[13] Ligji Nr. 8652, datë 31.07.2000 "Për organizimin dhe funksionimin e qeverisjes vendore", neni 1. [Online] Available: http://www.pad.gov.al/legiislacioni\%5C21QeverisjaVendore.pdf

[14] Lumanaj, B. (2013). Vlerësimi i shërbimeve sociale që ofrohen për familjen. Praktika dhe tendenca. (Vështrim në rajonet e Shqipërisë së Veriut). [Online] Available: http://www.doktoratura.unitir.edu.al/wpcontent/uploads/2014/01/Doktoratura-Brilanda-Lumanaj-Fakulteti-i-Shkencave-Sociale-Departamenti-PuneSociale.pdf 
[15] Munday, B., (2007). Report on user involvement in personal social services. Council of Europe. [Online] Available: www.hiproweb.org/...Services/.../6-A-4_User_invol... p. 34-37.

[16] Mbrotja Sociale në Shqipëri. Programet dhe Arritjet. Përgatitur nga IRPS në kuadër të projektit DILMA, Develop Integrated Labor Market of Adriatic area, financuar nga Komisioni Evropian.p.9.

[17] Strategjia e Shërbimeve Shoqërore (2005-2010). Tiranë, Shqipëri. [Online] Available: http://www.mpcs.gov.al/strategii-standarte

[18] The Youth Development Network, (2008). Report on the status and role of youth NGOs in the current democratic South Africa. p.35-37.

[19] Wax, A. L., (2003). Social Welfare, human dignity, and the puzzle of what we owe each other, Harvard Journal of Law \& Public Policy, 27(1), 121. 